\title{
$\checkmark$ Research Square \\ Barriers of Linkage to Hepatitis C Care and Treatment Among People Who Inject Drugs in Georgia
}

\author{
Maia Butsashvili ( $\nabla$ butsashvilimaia@gmail.com ) \\ Health Research Union https://orcid.org/0000-0002-6554-1567 \\ Tinatin Abzianidze \\ Health Research Union/Clinic NEOLAB
}

George Kamkamidze

Health Research Union/Clinic NEOLAB

Lasha Gulbiani

Health Research Union/Clinic NEOLAB

Lia Gvinjilia

TEPHINET

Tinatin Kuchuloria

TEPHINET

Irina Tskhomelidze

TEPHINET

Maka Gogia

Georgian Harm Reduction Network

Maia Tsereteli

National Center for Disease Control and Public Health

Veronique Miollany

Medicins Du Monde

Tamar Kikvidze

Medicins Du Monde

Shaun Shadaker

Centers for Disease Control and Prevention

Muazzam Nasrullah

Centers for Disease Control and Prevention

Francisco Averhoff

Centers for Disease Control and Prevention

\section{Research}

Keywords: PWID, Linkage to care, HCV, Elimination, Barriers

Posted Date: August 23rd, 2021 
DOI: https://doi.org/10.21203/rs.3.rs-151914/v2

License: (a) (i) This work is licensed under a Creative Commons Attribution 4.0 International License. Read Full License 


\section{Abstract}

Background: People who inject drugs (PWID) in Georgia have a high prevalence of hepatitis $\mathrm{C}$ virus antibody (anti-HCV). Access to care among PWID could be prioritized to meet the country's hepatitis $\mathrm{C}$ elimination goals. This study assesses barriers of linkage to hepatitis $C$ care among PWID in Georgia.

Methods: Study participants were enrolled from 13 harm reduction centers throughout Georgia. Anti-HCV positive PWID who were tested for viremia (linked to care [LC]), were compared to those not tested for viremia within 90 days of screening anti-HCV positive (not linked to care [NLC]). Participants were interviewed about potential barriers to seeking care.

Results: A total of 500 PWID were enrolled, 245 LC and 255 NLC. LC and NLC were similar with respect to gender, age, employment status, education, knowledge of anti-HCV status, and confidence/trust in the elimination program ( $p>0.05)$. More NLC $(13.0 \%)$ than LC $(7.4 \%)$ stated they were not sufficiently informed what to do after screening anti-HCV positive $(p<0.05)$. In multivariate analysis, linkage to care was associated with perceived affordability of the elimination program (adjusted prevalence ratio $=8.53 ; 95 \%$ confidence interval: 4.14-17.62).

Conclusions: Post testing counselling and making hepatitis C services affordable could help increase linkage to care among PWID in Georgia.

\section{Background}

Georgia, with a high burden of hepatitis C (Walker et al., 2020), embarked on a national program in 2015 to eliminate hepatitis C, with an overall goal of $90 \%$ reduction in hepatitis C virus (HCV) prevalence by 2020 (Ministry of Internally Displaced Persons from the Occupied Territories, Labor, Health and Social Affairs of Georgia, 2017). The country has one of the highest rates of injection drug use in the world (Degenhardt et al., 2017), and 66.2-92.0\% HCV antibody (anti-HCV) prevalence among people who inject drugs (PWID) (Bouscaillou et al., 2014) representing 25\% of all HCV cases in the country (Luhmann et al., 2015; Kikvidze et al., 2017). Increasing access to hepatitis $C$ screening, care and treatment among PWID is important if Georgia is to be successful in eliminating hepatitis $C$ from the country.

As of April 30, 2019, 56,294 patients had initiated hepatitis C treatment within the program, though there has been a gradual decline in the number of people initiating treatment since late 2016 (Averhoff et al., 2019). Despite extensive national screening activities, including among PWID at harm reduction (HR) centers, nearly half of Georgians with HCV infection are not aware of their HCV status (Averhoff et al., 2019). In addition, among those who have screened positive, a significant proportion have not received viremia testing to confirm active HCV infection, and among those with confirmed viremia, a significant proportion have not initiated antiviral treatment (Averhoff et al., 2019). PWID bear a disproportionate share of the HCV burden in the country (Chikovani et al., 2019) and ensuring access to treatment for this marginalized population is critical for achieving elimination in the country. However, barriers to accessing care in the national hepatitis $\mathrm{C}$ elimination program among anti-HCV-positive PWID are not well understood. The objective of this study was to assess barriers of linkage to HCV care among PWID in Georgia. 


\section{Methods}

All screening, viremia testing and treatment monitoring data are entered into the national elimination program database (Averhoff et al., 2019). Access to the database through a unique 11-digit national identification number (NIN) allows for tracking individuals across the whole continuum of care, from screening through treatment and testing for sustained viral response (SVR), i.e. cure.

\section{Study population}

There is a total of $13 \mathrm{HR}$ centers in the country (Ministry of Internally Displaced Persons from the Occupied Territories, Labor, Health and Social Affairs of Georgia, 2019). Since 2017, anti-HCV test results among PWIDs who agree to disclose their NIN are recorded in the elimination program database. During 2017-2018, a total of $2780 \mathrm{HR}$ center clients with positive test results for HCV antibody were identified in the program database by their NIN (Stvilia et al. 2019).

We compared PWIDs who were linked to HCV care (LC) with those who were not linked to care (NLC). Linkage to care was defined as receipt of HCV viremia testing within 90 days from the date of a positive anti-HCV result recorded in the hepatitis $C$ elimination program database. Convenience samples of $L C(n=263)$ and NLC $(n=275)$ individuals were drawn from the elimination program database by having hepatitis $C$ screening performed and recorded by an HR center using beneficiaries' NIN. LC were selected for having a positive antiHCV result dated between August 1, 2017 and January 31, 2018, while inclusion dates for NLC were between January 1, 2017 and January 31, 2018. The selection period for NLC had to be extended for 7 months to allow for more study participants with available and valid contact information.

\section{Data collection}

We conducted a telephone survey of LC and NLC PWID inquiring about potential barriers to obtaining viremia testing, and/or enrolling in the national hepatitis $C$ elimination program. Interviews were conducted from September 1, 2018 to December 20, 2018. Interviewers were recruited from HR center staff (HIV voluntary counseling and testing counselors) and trained prior to the study. Five attempts were made to reach each study participant. We calculated the proportion of individuals that were not reached via phone and those who refused to participate in the survey. The study protocol was approved by the Institutional Review Board of the Health Research Union (IRB00009520; IORG0005619).

\section{Survey tool}

The telephone questionnaire was developed and pilot tested among five respondents and adapted based on user feedback prior to administration. The questionnaire collected information about demographics and barriers to HCV care linkage. The social demographic characteristics included age, residence (capital city vs other regions), education, employment, family and personal income. Data collected on HCV included diagnostic test types available in the country, participant's HCV status and reasons for not being tested. The questionnaire also included questions about current use of HR services (some respondents who were HR center beneficiaries at the time of their anti-HCV test may no longer be receiving HR services at the time of interview), availability of medications, and procedure for enrollment in the program. Participants were also asked about affordability of the program; during the first three years (May 2015 - August 2018) when patients 
had a co-payment for diagnostic evaluations which was approximately 300 USD at the beginning of the program and later decreased to approximately 100 USD. We also gathered information on respondent preferences for type and source of information about HCV infection.

\section{Data analysis}

Following removal of identifying information, data were entered in Microsoft ${ }^{\circledR}$ Excel at study sites and imported in SPSS v.23 statistical software by the study statistician. Descriptive and bivariate analyses of factors associated with linkage to care were conducted. We calculated unadjusted and adjusted prevalence ratios (PR) with 95\% confidence intervals (Cl) to assess the associations between LC and NLC using logistic regression models.

\section{Results}

\section{Participation}

Out of the 538 participants drawn from the elimination program database that were approached, a total of 500 PWID participated in the study (refusal rate of $7.1 \%$ ); 245 were linked to care and 255 were not linked to care. The participation rates were similar when we compared LC and NLC.

\section{Demographic characteristics of study participants}

Overall, $91.2 \%$ of study subjects were males, $81.4 \%$ were older than 35 years, $63.8 \%$ were unemployed, and $34.9 \%$ had a university/college degree. No significant differences were found between the two groups (LC and NLC) by age, gender, residence, family income, employment status, education level, and confidence/trust in the hepatitis $\mathrm{C}$ elimination program (Table 1 ). 
Table 1

Comparison of linked to care (LC) and not linked to care (NLC) among people who inject drugs by different characteristics, Georgia

\begin{tabular}{|c|c|c|c|c|c|c|}
\hline \multirow[t]{2}{*}{ Characteristic } & \multicolumn{2}{|c|}{$\begin{array}{l}\text { Linked to } \\
\text { care (LC) }\end{array}$} & \multicolumn{2}{|c|}{$\begin{array}{l}\text { Not linked } \\
\text { to care } \\
\text { (NLC) }\end{array}$} & \multirow[t]{2}{*}{$\begin{array}{l}\text { Prevalence } \\
\text { Ratio (PR) } \\
\text { and } 95 \% \\
\mathrm{Cl}\end{array}$} & \multirow[t]{2}{*}{$\begin{array}{l}\text { Adjusted } \\
\text { Prevalence } \\
\text { Ratio (aPR) } \\
\text { and } 95 \% \text { Cl }\end{array}$} \\
\hline & $\mathbf{N}$ & $\%$ & $\mathbf{N}$ & $\%$ & & \\
\hline \multicolumn{7}{|l|}{ Gender } \\
\hline Male & 224 & 91.4 & 232 & 91.0 & $\begin{array}{l}1.01 \\
(0.95- \\
1.06)\end{array}$ & $\begin{array}{l}1.09 \\
(0.380-3.18)\end{array}$ \\
\hline Female & 21 & 8.6 & 23 & 9.0 & 1 & 1 \\
\hline \multicolumn{7}{|l|}{ Age } \\
\hline$\leq 35$ & 38 & 15.5 & 55 & 21.6 & $\begin{array}{l}1.20 \\
(0.99- \\
1.46)\end{array}$ & $\begin{array}{l}1.23(0.56- \\
2.69)\end{array}$ \\
\hline$>35$ & 207 & 84.5 & 200 & 78.4 & 1 & 1 \\
\hline \multicolumn{7}{|l|}{ Residence (district) } \\
\hline Tbilisi & 105 & 42.9 & 127 & 49.8 & 1 & 1 \\
\hline Regions & 140 & 57.1 & 128 & 50.2 & $\begin{array}{l}1.14 \\
(0.97- \\
1.34)\end{array}$ & $\begin{array}{l}0.8(0.36- \\
1.80)\end{array}$ \\
\hline \multicolumn{7}{|l|}{ Level of education* } \\
\hline University/Post-graduate & 80 & 33.3 & 91 & 36.4 & 1 & 1 \\
\hline Other & 160 & 66.7 & 159 & 63.6 & $\begin{array}{l}1.05 \\
(0.92- \\
1.19)\end{array}$ & $\begin{array}{l}1.96(0.94- \\
4.11)\end{array}$ \\
\hline \multicolumn{7}{|l|}{ Employment* } \\
\hline Employed & 92 & 38.0 & 87 & 34.4 & 1 & 1 \\
\hline Unemployed & 150 & 62.0 & 166 & 65.6 & $\begin{array}{l}0.95 \\
(0.83- \\
1.08)\end{array}$ & $\begin{array}{l}1.26(0.65- \\
2.57)\end{array}$ \\
\hline \multicolumn{7}{|l|}{ Family income (per month)* } \\
\hline$\leq 1000 \mathrm{GEL}$ & 122 & 87.8 & 133 & 90.5 & $\begin{array}{l}0.97 \\
(0.89- \\
1.05)\end{array}$ & $\begin{array}{l}1.21(0.42- \\
3.52)\end{array}$ \\
\hline > 1000 GEL & 17 & 12.2 & 14 & 9.5 & 1 & 1 \\
\hline
\end{tabular}




\begin{tabular}{|c|c|c|c|c|c|c|}
\hline \multirow[t]{2}{*}{ Characteristic } & \multicolumn{2}{|c|}{$\begin{array}{l}\text { Linked to } \\
\text { care (LC) }\end{array}$} & \multicolumn{2}{|c|}{$\begin{array}{l}\text { Not linked } \\
\text { to care } \\
\text { (NLC) }\end{array}$} & \multirow[t]{2}{*}{$\begin{array}{l}\text { Prevalence } \\
\text { Ratio (PR) } \\
\text { and } 95 \% \\
\mathrm{Cl}\end{array}$} & \multirow[t]{2}{*}{$\begin{array}{l}\text { Adjusted } \\
\text { Prevalence } \\
\text { Ratio (aPR) } \\
\text { and } 95 \% \text { Cl }\end{array}$} \\
\hline & $\mathbf{N}$ & $\%$ & $\mathbf{N}$ & $\%$ & & \\
\hline Yes & 182 & 75.5 & 105 & 41.8 & $\begin{array}{l}1.81 \\
(1.53- \\
2.12)\end{array}$ & $\begin{array}{l}8.53(4.14- \\
17.62)\end{array}$ \\
\hline No & 59 & 24.5 & 146 & 58.2 & 1 & 1 \\
\hline \multicolumn{7}{|c|}{$\begin{array}{l}\text { Who notified you about the screening test } \\
\text { result?*}\end{array}$} \\
\hline Person who conducted the test & 64 & 33.2 & 56 & 28.3 & $\begin{array}{l}1.17 \\
(0.87- \\
1.58)\end{array}$ & $\begin{array}{l}1.02(0.67- \\
1.23)\end{array}$ \\
\hline Physician/Consultant & 129 & 66.8 & 142 & 71.7 & 1 & 1 \\
\hline \multicolumn{7}{|c|}{$\begin{array}{l}\text { Do you feel that you received sufficient } \\
\text { information to know what to do next after } \\
\text { screening test?*}\end{array}$} \\
\hline Yes & 226 & 92.6 & 220 & 87.0 & $\begin{array}{l}1.07 \\
(1.01- \\
1.13)\end{array}$ & $\begin{array}{l}0.61(0.17- \\
1.99)\end{array}$ \\
\hline No & 18 & 7.4 & 33 & 13.0 & 1 & 1 \\
\hline \multicolumn{7}{|c|}{ Trusting HCV elimination program* } \\
\hline Yes & 231 & 95.1 & 236 & 92.5 & 1 & 1 \\
\hline No & 12 & 4.9 & 19 & 7.5 & $\begin{array}{l}0.66 \\
(0.33- \\
1.33)\end{array}$ & $\begin{array}{l}0.73(0.13- \\
4.09)\end{array}$ \\
\hline \multicolumn{7}{|c|}{$\begin{array}{l}\text { Do you currently use the services in HR } \\
\text { centers?* }\end{array}$} \\
\hline Yes & 111 & 48.7 & 90 & 37.3 & $\begin{array}{l}1.31 \\
(1.07- \\
1.61)\end{array}$ & $\begin{array}{l}1.21(0.91- \\
1.52)\end{array}$ \\
\hline No & 117 & 51.3 & 151 & 62.7 & 1 & 1 \\
\hline \multicolumn{7}{|c|}{$\begin{array}{l}\text { Would it be more comfortable if HCV } \\
\text { treatment were available in HR centers?* }\end{array}$} \\
\hline Yes & 169 & 84.9 & 190 & 86.4 & $\begin{array}{l}0.98 \\
(0.91- \\
1.06)\end{array}$ & $\begin{array}{l}0.65(0.32- \\
1.29)\end{array}$ \\
\hline No & 30 & 15.1 & 30 & 13.6 & 1 & 1 \\
\hline
\end{tabular}




\begin{tabular}{|c|c|c|c|c|c|c|}
\hline \multirow[t]{2}{*}{ Characteristic } & \multicolumn{2}{|c|}{$\begin{array}{l}\text { Linked to } \\
\text { care (LC) }\end{array}$} & \multicolumn{2}{|c|}{$\begin{array}{l}\text { Not linked } \\
\text { to care } \\
\text { (NLC) }\end{array}$} & \multirow[t]{2}{*}{$\begin{array}{l}\text { Prevalence } \\
\text { Ratio (PR) } \\
\text { and } 95 \% \\
\mathrm{Cl}\end{array}$} & \multirow[t]{2}{*}{$\begin{array}{l}\text { Adjusted } \\
\text { Prevalence } \\
\text { Ratio (aPR) } \\
\text { and } 95 \% \text { Cl }\end{array}$} \\
\hline & $\mathbf{N}$ & $\%$ & $\mathbf{N}$ & $\%$ & & \\
\hline \multicolumn{7}{|c|}{ *Missing values not shown } \\
\hline \multicolumn{7}{|c|}{ Abbreviations: $\mathrm{Cl}=$ confidence interval, $\mathrm{HCV}=$ hepatitis $\mathrm{C}$ virus, $\mathrm{GEL}=$ Georgian lari, $\mathrm{HR}=$ harm reduction } \\
\hline
\end{tabular}

\section{Knowledge of HCV and elimination program}

Most of the study participants (98.2\%) were aware of their HCV infection. Of the surveyed individuals, 391 (78.2\%) reported that they had been informed about HCV test results from a health care worker ( $\mathrm{HCW})$.

When we looked at reasons why the NLC group did not receive viremia testing, 21.7\% stated that the reason was cost of the testing, and $42.9 \%$ of the NLC group stated that a free laboratory test would improve enrollment in the program. A quarter (24.5\%) of NLC participants expressed willingness to receive more information about $\mathrm{HCV}$ infection and the hepatitis $\mathrm{C}$ elimination program, preferring television and the internet as sources of information.

\section{Association of linkage to care with different factors}

In bivariate analysis, when comparing those linked and not linked to HCV care, $13.0 \%$ of NLC compared to $7.4 \%$ of LC stated they did not receive sufficient information to know what to do next after their positive screening test $(P R=1.07 ; 95 \% \mathrm{Cl}: 1.01-1.13)$. More NLC (58.2\%) than LC (24.5\%) reported that enrollment was not affordable ( $P R=1.81 ; 95 \% \mathrm{Cl}$ : 1.53-2.12). Ongoing engagement in HR services was associated with linkage to care (PR $=1.31 ; 95 \% \mathrm{Cl}: 1.07-1.61)$. Nearly $85 \%$ of $L C$ and $86.4 \%$ of NLC think that it would be more comfortable if $\mathrm{HCV}$ treatment were available at $\mathrm{HR}$ centers $(\mathrm{PR}=0.98 ; 95 \% \mathrm{Cl}: 0.91-1.06)$. However, in multivariate analysis, the only independent predictor of linkage to care was affordability of the program (adjusted PR = 8.53; 95\% Cl: 4.14-17.62) (Table 1).

\section{Discussion}

This is the first quantitative study in Georgia to examine barriers to HCV treatment among PWID, which represents a priority for the program. Mathematical modeling suggests that for countries with a large burden of injection drug use, HCV treatment for PWID is critical to achieving HCV elimination (Pitcher et al., 2019). We found that barriers to linkage to care among anti-HCV positive PWID include perceived high cost of care and a lack of information on what to do after a positive screening.

The eligibility criteria for HCV-infected individuals to enroll in the hepatitis C elimination program in Georgia are simple i.e., a person must be a citizen of Georgia aged $\geq 18$ years. At the beginning of the program (April 28, 2015 to June 9, 2016) only patients with advanced liver fibrosis level were eligible for treatment (Mitruka et al., 2015). However, since June, 2016, the program has been expanded to all HCV-viremic individuals regardless of disease severity (Nasrullah et al., 2017). This expansion resulted in an increase in the number of enrolled individuals, but enrollment gradually declined after its peak in September 2016. Exact reasons for this 
decline are not known but high cost of diagnostics earlier in the program may be attributed to this decline. In our analysis, affordability of the program was the only independent predictor of linkage to care.

Although all PWID interviewed were utilizing HR services at the time they were screened, more than half of study participants were no longer receiving HR services at the time of interview. Disengagement with HR services was one of the factors associated with poor linkage to care. Research suggests engagement in opioid substitution therapy and other HR services increases linkage to care among PWID (Bouscaillou et al., 2018). Our data seem to correlate with this finding.

One important finding of this study was that more than $20 \%$ of respondents did not indicate they were informed of their test results by a HCW. Ensuring counseling to communicate screening test results and the need and procedure for follow-up viremia testing among those with positive screening results may result in increased linkage to care. Further, standardized counseling procedures need to be developed and implemented at all HR facilities to inform anti-HCV-positive patients about the need for HCV viremia testing to improve linkage to care.

This study is subject to limitations. Firstly, our findings are not representative of all PWID in the country. We were unable to include those PWID in our study who were not enrolled in HR service at the time of anti-HCV testing and who did not agree to provide NIN to be registered in the elimination program database. Individuals not enrolled in HR services are likely among the hardest to reach, and we were not able to survey this population. Secondly, these findings are self-reported and are subject to recall and social desirability biases. Another limitation of the study is different selection period for NLC and LC groups (longer selection period for NLC), which could lead to information bias, as awareness of the study participants could change over time.

Interventions to improve linkage to hepatitis $\mathrm{C}$ care among PWID have been identified by different studies. One study found increased enrollment rates and adherence to treatment among PWID with advanced liver fibrosis level when hepatitis $\mathrm{C}$ screening is done on-site (at the HR center) and when peer navigation services are available (Kikvidze et al., 2018).

Because of technical advisory group (TAG) recommendations in Georgia and our study findings, the government has made all diagnostics free of charge since September, 2018. Other services, such as on-site viremia testing and treatment have also been shown to be effective (Chihota et al., 2018), and could help the country to reach elimination.

\section{Conclusions}

Post testing counselling and making hepatitis $C$ services affordable could help increase linkage to care among PWID in Georgia. Reducing barriers for PWID is critical, and data from this study may be useful for other countries with a high HCV prevalence and where injection drug use is a major route of HCV transmission.

\section{Abbreviations}

HCV - Hepatitis C virus 
HIV - Human Immunodeficiency Virus

HR - Harm Reduction

LC - Linked to Care

NIN - National Identification Number

NLC - Not Linked to Care

PWID - People Who Inject Drugs

TAG - Technical Advisory Group

USD - United States Dollar

\section{Declarations}

\section{Disclaimer}

The findings and conclusions in this report are those of the authors and do not necessarily represent the official position of the U.S. Centers for Disease Control and Prevention.

Ethics approval and consent to participate: The authors declare that they have no known competing financial interests or personal relationships that could have appeared to influence the work reported in this paper. The study was approved by institutional review board of Health Research Union (IRB\#00009520).

Consent for publication: Not applicable.

Availability of data and materials: All data generated or analysed during this study are included in this published article.

Competing interests: The authors declare that they have no competing interests.

Funding: This work was supported by CDC Foundation [grant number 807] and Medecins Du Monde France Representation in Georgia.

Authors' contributions: MB developed the study design and supervised data collection, analysis and manuscript preparation activities; TA and LG participated in data collection, entry and analysis and manuscript writing; TK developed study instrument; MG supervised pilot testing among study respondents; GK verified the analytical methods and performed statistical analysis; The concept for the study was developed with LG, TK, IT and MT; All authors contributed to interpretation of results, writing report, edited and approved the final manuscript.

Acknowledgements: This work was supported by CDC Foundation [grant number 807] and Medecins Du Monde France Representation in Georgia. 


\section{References}

1. Averhoff, F., Lazarus, J. V., Sergeenko, D., Colombo, M., Gamkrelidze, A., Tsertsvadze, T., Butsashvili, M., Metreveli, D., Sharvadze, L., Hellard, M., Gnes, S., Gabunia, T., \& Nasrullah, M. (2019). Excellence in viral hepatitis elimination - Lessons from Georgia. Journal of hepatology, 71(4), 645-647. https://doi.org/10.1016/j.jhep.2019.06.026

2. Bouscaillou, J., Champagnat, J., Luhmann, N., Avril, E., Inaridze, I., Miollany, V., Labartkava, K., Kirtadze, I., Butsashvili, M., Kamkamidze, G., \& Pataut, D. (2014). Hepatitis C among people who inject drugs in Tbilisi, Georgia: an urgent need for prevention and treatment. The International journal on drug policy, 25(5), 871-878. https://doi.org/10.1016/j.drugpo.2014.01.007

3. Bouscaillou, J., Kikvidze, T., Butsashvili, M., Labartkava, K., Inaridze, I., Etienne, A., Le Pluart, D., Kamkamidze, G., Gamezardashvili, A., Kharshiladze, D., Avril, E., \& Luhmann, N. (2018). Direct acting antiviral-based treatment of hepatitis $\mathrm{C}$ virus infection among people who inject drugs in Georgia: $\mathrm{A}$ prospective cohort study. The International journal on drug policy, 62, 104-111. https://doi.org/10.1016/j.drugpo.2018.07.016

4. Chihota, V., Japaridze, M., Shilton, S., Ruiz, R., Francois Lamoury O’Brien, .J, Khonelidze, I., Butsashvili, M., Alkazashvili, M., Marinucci, F. (2018). Approaches to providing hepatitis C viremia testing to people who inject drugs in Georgia. Abstract retrieved from https://www.moh.gov.ge/uploads/files/2019/Failebi/25.04.2019-2.pdf

5. Chikovani, I., Ompad, D. C., Uchaneishvili, M., Sulaberidze, L., Sikharulidze, K., Hagan, H., \& Van Devanter, N. L. (2019). On the way to Hepatitis C elimination in the Republic of Georgia-Barriers and facilitators for people who inject drugs for engaging in the treatment program: A formative qualitative study. PloS one, 14(4), e0216123. https://doi.org/10.1371/journal.pone.0216123

6. Degenhardt, L., Peacock, A., Colledge, S., Leung, J., Grebely, J., Vickerman, P., Stone, J., Cunningham, E. B., Trickey, A., Dumchev, K., Lynskey, M., Griffiths, P., Mattick, R. P., Hickman, M., \& Larney, S. (2017). Global prevalence of injecting drug use and sociodemographic characteristics and prevalence of HIV, HBV, and HCV in people who inject drugs: a multistage systematic review. The Lancet. Global health, 5(12), e1192e1207. https://doi.org/10.1016/S2214-109X(17)30375-3

7. Kikvidze, T., Luhmann, N., Avril, E., Butsashvili, M., Labartkava, K., Etienne, A., Le Pluart, D., Inaridze, I., Gamezardashvili, A., Kharshiladze, D., \& Bouscaillou, J. (2018). Harm reduction-based and peer-supported hepatitis $C$ treatment for people who inject drugs in Georgia. The International journal on drug policy, 52, 16-19. https://doi.org/10.1016/j.drugpo.2017.11.014

8. Luhmann, N., Champagnat, J., Golovin, S., Maistat, L., Agustian, E., Inaridze, I., et al. (2015). Access to hepatitis $C$ treatment for people who inject drugs in low and middle income settings: Evidence from 5 countries in Eastern Europe and Asia. International Journal of Drug Policy, 26(11), 1081-1087

9. Ministry of Internally Displaced Persons from the Occupied Territories, Labour, Health and Social Affairs of Georgia (2017). Strategic plan for the elimination of hepatitis C virus in Georgia, 2016-2020. Retrieved $25^{\text {th }}$ of May 2020 from

https://www.moh.gov.ge/uploads/files/2017/akordeoni/failebi/Georgia_HCV_Elimination_Strategy_20162020.pdf 
10. Ministry of Internally Displaced Persons from the Occupied Territories, Labour, Health and Social Affairs of Georgia (2019). National hepatitis C virus elimination program report. Georgia, 2015-2017. Retrieved $19^{\text {th }}$ of June 2020 from https://www.moh.gov.ge/uploads/files/2019/Failebi/25.04.2019-1.pdf

11. Mitruka, K., Tsertsvadze, T., Butsashvili, M., Gamkrelidze, A., Sabelashvili, P., Adamia, E., Chokheli, M., Drobeniuc, J., Hagan, L., Harris, A. M., Jiqia, T., Kasradze, A., Ko, S., Qerashvili, V., Sharvadze, L., Tskhomelidze, I., Kvaratskhelia, V., Morgan, J., Ward, J. W., \& Averhoff, F. (2015). Launch of a Nationwide Hepatitis C Elimination Program-Georgia, April 2015. MMWR. Morbidity and mortality weekly report, 64(28), 753-757. https://doi.org/10.15585/mmwr.mm6428a2

12. Nasrullah, M., Sergeenko, D., Gvinjilia, L., Gamkrelidze, A., Tsertsvadze, T., Butsashvili, M., Metreveli, D., Sharvadze, L., Alkhazashvili, M., Shadaker, S., Ward, J. W., Morgan, J., \& Averhoff, F. (2017). The Role of Screening and Treatment in National Progress Toward Hepatitis C Elimination - Georgia, 2015-2016. MMWR. Morbidity and mortality weekly report, 66(29), 773-776.

https://doi.org/10.15585/mmwr.mm6629a2

13. Pitcher, A. B., Borquez, A., Skaathun, B., \& Martin, N. K. (2019). Mathematical modeling of hepatitis c virus (HCV) prevention among people who inject drugs: A review of the literature and insights for elimination strategies. Journal of theoretical biology, 481, 194-201. https://doi.org/10.1016/j.jtbi.2018.11.013

14. Stvilia K, Spradling PR, Asatiani A, Gogia M, Kutateladze K, Butsashvili M, Zarkua J, Tsertsvadze T, Sharvadze L, Japaridze M, Kuchuloria T, Gvinjilia L, Tskhomelidze I, Gamkrelidze A, Khonelidze I, Sergeenko D, Shadaker S, Averhoff F, Nasrullah M. Progress in Testing for and Treatment of Hepatitis C Virus Infection Among Persons Who Inject Drugs - Georgia, 2018. MMWR Morb Mortal Wkly Rep. 2019;68(29):637-641. Published 2019 Jul 26. doi:10.15585/mmwr.mm6829a2

15. Walker, J. G., Kuchuloria, T., Sergeenko, D., Fraser, H., Lim, A. G., Shadaker, S., Hagan, L., Gamkrelidze, A., Kvaratskhelia, V., Gvinjilia, L., Aladashvili, M., Asatiani, A., Baliashvili, D., Butsashvili, M., Chikovani, I., Khonelidze, I., Kirtadze, I., Kuniholm, M. H., Otiashvili, D., Sharvadze, L., ... Vickerman, P. (2020). Interim effect evaluation of the hepatitis $\mathrm{C}$ elimination programme in Georgia: a modelling study. The Lancet. Global health, 8(2), e244-e253. https://doi.org/10.1016/S2214-109X(19)30483-8 